\title{
SISTEM PENDUKUNG KEPUTUSAN PEMILIHAN SKINCARE YANG SESUAI DENGAN JENIS KULIT WAJAH MENGGUNAKAN LOGIKA FUZZY
}

\author{
Vadlya Maarif ${ }^{1}$, Hidayat Muhammad Nur ${ }^{2}$, Tri Ayu Septianisa ${ }^{3}$ \\ ${ }^{1}$ Sistem Informasi, STMIK Nusa Mandiri \\ ${ }^{2}$ Sistem Informasi, ${ }^{3}$ Teknologi Komputer Universitas Bina Sarana Informatika, \\ email: ${ }^{1}$ vadlya.vlr@nusamandiri.ac.id, ${ }^{2}$ hidayat.hmm@bsi.ac.id, ${ }^{3}$ triayuseptianisa@gmail.com
}

\begin{abstract}
Have attractive appearance and a beautiful face is something that every woman desires. However, the attractive appearance is not only seen from the clothes and all the accessories they wear, but also supported by the presence of healthy skin. Skin is the most important part that must be treated and maintained. Skincare is a procedure or steps for skin care that is carried out using skincare products and beauty cosmetics with ingredients that are safe and well used according to the skin type of each individual face. Before doing skincare the most important thing is to know the type of skin on each of our faces.In the process of designing decision support system applications the selection of skincare according to facial skin type uses fuzzy logic. This research was chosen because it was able to select the best alternative from a number of alternatives. In this case the intended alternative is selected facial foam products based on the specified criteria. This decision support system can provide an alternative decision on selected products that can later be used as a reference to determine the product that suits the type of facial skin. Applications are made using Basic For Android (B4A), with Basic programming languages, and software support tools such as Paint and Photoshop. The design of this application is the best solution to solve problems that exist on facial skin. This application is expected to be more effective, especially in terms of making decisions.
\end{abstract}

\section{Keyword: Face Skin, Skincare, Fuzzy Logic, Decision Support System.}

Abstrak- Memiliki penampilan menarik serta wajah yang cantik merupakan hal yang diidamkan oleh setiap wanita.Namun, penampilan yang menarik bukan hanya dilihat dari pakaian dan segala aksesoris yang dipakainya, melaikan ditunjang dengan adanya kulit yang sehat.Kulit merupakan bagian paling penting yang harus dirawat dan dijaga.Perawatan kulit (skincare) adalah prosedur atau langkah-langkah merawat kulit yang dilakukan dengan menggunakan produk-produk skincare dan kosmetik kecantikan dengan kandungan bahan yang aman serta baik digunakan sesuai dengan jenis kulit wajah masing-masing individu. Sebelum melakukan perawatan kulit hal yang paling utama adalah mengetahui jenis kulit wajah kita masing-masing. Dalam proses perancangan aplikasi sistem pendukung keputusan pemilihan skincare yang sesuai dengan jenis kulit wajah menggunakan logika fuzzy. Penelitian ini dipilih karena mampu menyeleksi alternatif terbaik dari sejumlah alternatif yang ada.Dalam hal ini alternatif yang dimaksudkan yaitu produk facial foam yang terpilih berdasarkan kriteria-kriteria yang ditentukan.Sistem pendukung keputusan ini dapat memberikan keputusan alternatif produk terpilih yang nantinya dapat dijadikan sebagai acuan untuk menentukan produk yang sesuai dengan jenis kulit wajah. Aplikasi dibuat dengan menggunakan Basic For Android (B4A), dengan bahasa pemograman Basic, dan sarana pendukung software seperti Paint dan Photoshop. Perancangan aplikasi ini merupakan solusi terbaik untuk memecahkan permasalahan yang ada pada kulit wajah.Aplikasi ini diharapkan dapat lebih efektif terutama dalam hal membuat keputusan.

\section{Kata Kunci: Kulit Wajah, Skincare, Logika Fuzzy, Sistem Pendukung Keputusan.}

\section{A. PENDAHULUAN}

Memiliki penampilan menarik serta wajah yang cantik merupakan hal yang diidamkan oleh setiap wanita.Namun, penampilan yang menarik bukan hanya dilihat dari pakaian dan segala aksesoris yang dipakainya, melaikan ditunjang dengan adanya kulit yang sehat.Kulit merupakan bagian paling penting yang harus dirawat dan dijaga.Perawatan kulit (skincare) adalah prosedur atau langkah-langkah merawat kulit yang dilakukan dengan menggunakan produk-produk skincare dan kosmetik kecantikan dengan kandungan bahan yang aman serta baik digunakan sesuai dengan jenis kulit wajah masing-masing individu.Sebelum melakukan perawatan kulit hal yang paling utama adalah mengetahui jenis kulit wajah kita masing-masing.Jenis kulit wajah yang umum dimiliki oleh manusia yaitu kulit wajah normal, berminyak, dan 
kering.Menyadari bahwa setiap manusia memiliki jenis kulit wajah yang berbeda, maka permasalahan yang muncul pada kulit wajah pun beragam mulai dari timbulnya jerawat, flek hitam, wajah kusam, berkomedo, dan lain sebagainya. Maryani tahun 2017 telah melakukan penelitian yang berjudul Sistem Pendukung Keputusan Pemilihan Kosmetik Produk Latulipe Yang Sesuai Dengan Jenis Kulit Wajah Perempuan Indonesia Menggunakan Metode Promethee yang bertujuan untuk memudahkan bagi pihak manajemen perusahaan kosmetik agar dapat mengetahui secara lebih rinci tentang pemilihan kosmetik latulipe yang sesuai dengan jenis kulit wajah, lebih mudah mengetahui kriteria konsumen, memudahkan manajemen untuk menentukan kosmetik latulipe apa yang cocok untuk jenis kulit wajah konsumen tersebut berdasarkan kriteria kulit wajah konsumen

Timbulnya masalah kulit wajah tersebut bisa disebabkan oleh faktor penggunaan produk skincare dan kosmetik kecantikan yang mengandung bahan berbahaya untuk kulit wajah atau terjadi karena adanya faktor dari dalam tubuh sendiri maupun pengaruh lingkungan luar.Mengingat banyak faktor yang dapat mengakibatkan kulit bermasalah, maka untuk merawat dan mengatasi kulit bermasalah dibutuhkan jenis perawatan yang tepat, sedangkan biaya yang dikeluarkan jika konsultasi langsung pada klinik atau salon kecantikan memerlukan biaya yang cukup banyak.

\section{B. TINJAUAN PUSTAKA}

\section{Program}

Menurut Yuswanto dalam (Astika et al., 2017): Program merupakan kata, ekspresi pernyataan atau kombinasi yang disusun dan dirangkai menjadi satu kesatuan prosedur, berupa urutan langkah untuk menyelesaikan masalah yang diimplementasikan dengan menggunakan bahasa pemograman sehingga dapat dieksekusi oleh komputer.

\section{Aplikasi}

Menurut Kamus Besar Bahasa Indonesia (KBBI) dalam (Maarif et al., 2018) : Pengertian aplikasi menurut Kamus Besar Bahasa Indonesia $(\mathrm{KBBI})$ adalah penerapan dari rancang sistem untuk mengolah data yang menggunakan aturan atau ketentuan bahasa pemrograman tertentu. Aplikasi adalah suatu program komputer yang dibuat untuk mengerjakan dan melaksanakan tugas khusus dari user (pengguna).

\section{Android}

Menurut Safaat dalam (Maarif et al., 2018) "Android adalah sebuah sistem operasi untuk perangkat mobile berbasis linux yang mencangkup sistem operasi, middleware dan aplikasi. Android menyediakan platformterbuka bagi para pengembang untuk menciptakan aplikasi mereka".

\section{Sistem Pendukung Keputusan (Decision Suport System)}

Menurut Alter dalam (Sari, 2016) : Sistem pendukung keputusan (SPK) merupakan sistem informasi interaktif yang menyediakan informasi, pemodelan dan pemanipulasian data. Sistem itu digunakan untuk membantu pengambilan keputusan dalam situasi yang semiterstruktur dan situasi yang tidak terstruktur, dimana tidak seorangpun tau secara pasti bagaimana keputusan dibuat.

Penyusunan sebuah model keputusan merupakan suatu cara untuk mengembangkan hubungan-hubungan logis yang mendasari persoalan keputusan ke dalam suatu bentuk model matematis, yang mencerminkan hubungan diantara faktor-faktor yang terlibat. Model yang menggambarkan proses pengembalian keputusan terdiri dari empat fase yaitu :

a) Penelusuran (Intelligence)

Tahap ini merupakan tahap pendefinisian masalah serta identifikasi informasi yang dibutuhkan yang berkaitan dengan persoalan yang dihadapi serta keputusan yang akan diambil.

b) Perancangan (Design)

Suatu proses untuk mempersentasi kan model sistem yang akan dibangun berdasarkan pada asumsi yang telah ditetapkan. Dalam tahap ini, suatu model dari masalah dibuat, diuji, dan divalidasi.

c) Pemilihan (Choice)

Suatu proses melakukan pengujian dan memilih keputusan terbaik berdasarkan kriteria tertentu yang telah ditentukan dan memberikan pengaruh kepada tujuan yang akan dicapai.

d) Implementasi (Implementation)

Tahap pelaksanaan dari keputusan yang telah diambil.Pada tahap ini perlu disusun serangkaian tindakan yang terencana, sehingga hasil keputusan dapat dipantau dan disesuaikan apabila diperlukan perbaikan-perbaikan. 


\section{Logika Fuzzy (Fuzzy Logic)}

Menurut Kusumadewi \& Purnomo dalam (Firmansyah, 2017) : Fuzzy Logic adalah salah satu komponen pembentuk soft computing. Fuzzy Logic pertama kali diperkenalkan oleh Prof. Lotfi A. Zadeh pada tahun 1965.Dasar Fuzzy Logic adalah teori himpunan Fuzzy.Pada teori himpunan Fuzzy, peranan derajat keanggotaan sebagai penentu keberadaan elemen dalam suatu himpunan sangatlah penting.Nilai keanggotaan atau derajat keanggotaan atau membership function menjadi ciri utama dalam penalaran dengan Fuzzy Logic tersebut.Fuzzy Logic dapat dianggap sebagai kotak hitam yang berhubungan antara ruang input menuju ruang output. Kotak hitam tersebut berisi cara atau metode yang dapat digunakan untuk mengolah data input menjadi output dalam bentuk

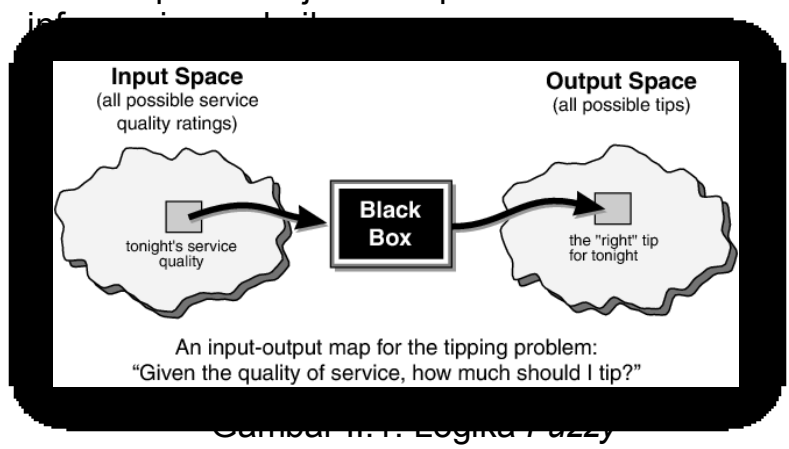

\section{HIPO}

Menurut (Riza et al., 2018) HIPO (Hierarchy Plus Input Process Output) merupakan alat desain dan tehnik dokumentasi dalam siklus perkembangan sistem dari top level sistem utama sampai level 1 percabangan dari input, process dan output.

\section{Flowchart}

Menurut Sitorus dalam (Maarif et al., 2018) pengertian flowchart, "Merupakan langkah penyelesaian masalah yang dituliskan dalam simbol-simbol tertentu". Diagram ini menunjukan cara kerja program secara logika, juga sangat diperlukan sebagai alat komunikasi dan dokumentasi.

\section{METODE PENELITIAN}

Metode yang digunakan pada penilitian ini yaitu :

\section{Metode Wawancara (Interview)}

Penulis mengajukan pertanyaan secara lisan kepada narasumber yang mempunyai pengetahuan tentang produk-produk skincare.

\section{Metode Pengamatan Langsung (Observasi)}

Penulis melakukan pengamatan langsung ke tempat penjualan segala jenis produk skincare.

\section{Metode Studi Pustaka}

Pada metode ini dilakukan studi pustaka atau mencari referensi dari buku, jurnal atau literature yang berkaitan tentang produk skincare.

\section{HASIL DAN PEMBAHASAN}

\section{Metode Algoritma Variabel Fuzzy}

Dalam rancangan algoritma penulis menggunakan variabel fuzzy untuk menghitung kriteria pemilihan produk skincare yang dibutuhkan. Produk skincare memiliki karakteristik yang menunjukan sifat dari produk skincare seperti jenis kulit, kadar $\mathrm{PH}$, kemasan, dan harga. Karakteristik produk skincare ini pada umumnya digunakan untuk pertimbangan pemilihan produk skincare, oleh karena itu karakteristik tersebut dijadikan variabel fuzzy dalam sistem pendukung keputusan ini. Berikut variabel-variabel fuzzy yang digunakan:

\section{a) Jenis Kulit}

Setiap orang memiliki jenis kulit wajah yang berbeda-beda.Ada 3 jenis kulit wajah yang umum dimiliki seperti jenis kulit wajah kering, normal, dan berminyak.Sebagai contoh jenis kulit kering diberi nilai dengan angka 1 (satu), jenis kulit normal diberi nilai dengan angka 2 (dua), dan jenis kulit berminyak diberi nilai dengan angka 3 (tiga).

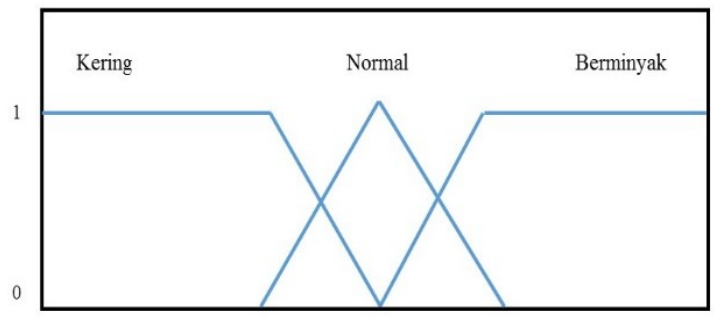

Gambar III.22. Fưngsi Keanggotaan Pada Variabel Jenis Kulit

Fungsi Keanggotaan :

$\mu$ Kering $[\mathrm{x}]=\left[\begin{array}{c}1 ; x \leq 1 \\ \frac{2-x}{1} ; 1 \leq x \leq 2 \\ 0 ; x \geq 2\end{array}\right]$ 
$\mu$ Normal $[x]=\left[\begin{array}{c}0 ; x \leq 1 \text { atau } x \leq 3 \\ \frac{x-1}{1} ; 1 \leq x \leq 2 \\ \frac{3-x}{1} ; 2 \leq x \leq 3\end{array}\right]$

$\mu$ Berminyak $[\mathrm{X}]=\left[\begin{array}{c}0 ; x \leq 3 \\ \frac{3-x}{1} ; 2 \leq x \leq 3 \\ 1 ; x \geq 3\end{array}\right]$

b) Kadar PH (Potential Hydrogen)

Dari semua produk facial foam yang teliti didapat kadar ph yang berbeda. Kadar PH 5,0 untuk rendah. 6,0 untuk kadar $\mathrm{PH}$ sedang dan 7,0 untuk kadar $\mathrm{PH}$ tinggi.

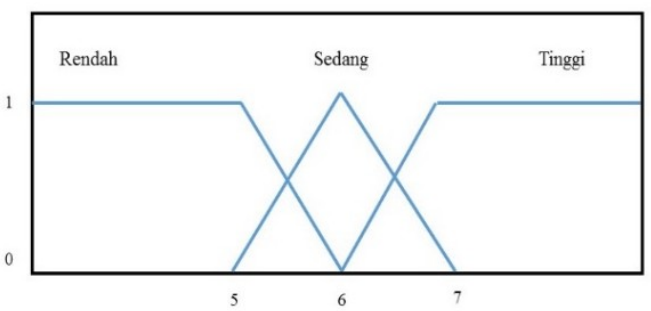

Gambar III.23. Fungsi Keanggotaan Pada Variabel Kadar PH

Fungsi Keanggotaan :

$\mu \operatorname{Rendah}[\mathrm{x}]=\left[\begin{array}{c}1 ; x \leq 5 \\ \frac{6-x}{1} ; \quad 5 \leq x \leq 6 \\ 0 ; x \geq 6\end{array}\right]$

$\mu$ Sedang $[\mathrm{x}]=\left[\begin{array}{c}0 ; x \leq 5 \text { atau } x \leq 7 \\ \frac{x-5}{1} ; 5 \leq x \leq 6 \\ \frac{7-x}{1} ; 6 \leq x \leq 7\end{array}\right]$

$\mu$ Tinggi $[x]=\left[\begin{array}{c}0 ; x \leq 6 \\ \frac{7-x}{1} ; 6 \leq x \leq 7 \\ 1 ; x \geq 7\end{array}\right]$

c) Kemasan

Dari semua produk facial foam yang teliti didapat kemasan dengan ukuran yang berbeda. Kemasan kecil berukuran 40-50 gr $/ \mathrm{ml}$. kemasan berukuran sedang $60-80 \mathrm{gr} / \mathrm{ml}$. Dan kemasan berukuran besar $100-110 \mathrm{gr} / \mathrm{ml}$.

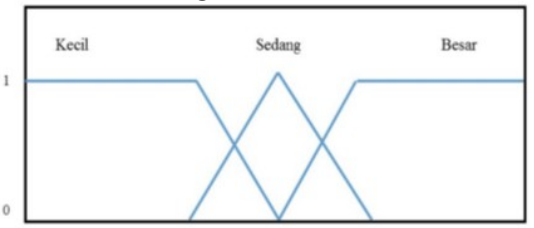

Gambar III.24. Fungsi Keanggotaan Pada Variabel Kemasan
Fungsi Keanggotaan :

$\mu \operatorname{Kecil}[\mathrm{x}]=\left[\begin{array}{c}1 ; x \leq 40 \\ \frac{80-x}{40} ; \quad 40 \leq x \leq 80 \\ 0 ; x \geq 80\end{array}\right]$

$\mu$ Sedang $[\mathrm{x}]=\left[\begin{array}{l}0 ; x \leq 40 \text { atau } x \leq 110 \\ \frac{x-40}{40} ; 40 \leq x \leq 80 \\ 110-x \ldots \ldots\end{array}\right]$

$\mu \operatorname{Besar}[\mathrm{x}]=\left[\begin{array}{c}0 ; x \leq 80 \\ \frac{110-x}{30} ; 80 \leq x \leq 110 \\ 1 ; x \geq 110\end{array}\right]$

d) Harga

Menurut Tjiptono dalam Prakoso (2015) menyatakan "Dari sudut pandang konsumen harga sering kali digunakan sebagai indikator nilai bilamana harga tersebut dihubungakn dengan manfaat yang dirasakan atas barang atau jasa".

Dari semua produk facial foam yang teliti didapat harga terendah produk facial foam adalah pigeon sebesar Rp.10.700. harga tertinggi adalah dove sebesar Rp.26.800. dan harga sedang digunakan harga Rp.17.000.

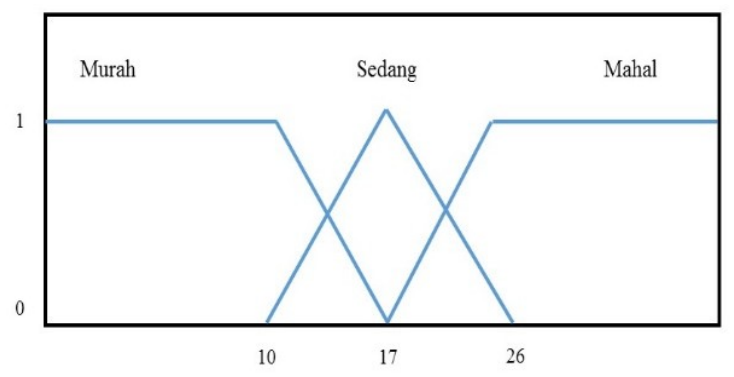

Gambar III.25. Fungsi Keanggotaan Pada Variabel Harga (belasan hingga puluhan ribu)

Fungsi Keanggotaan:

$\mu$ HargaMurah $[\mathrm{x}]=\left[\begin{array}{c}1 ; x \leq 10 \\ \frac{17-x}{7} ; 10 \leq x \leq 17 \\ 0 ; x \geq 17\end{array}\right]$

$\mu \mathrm{HargaSedang}[\mathrm{X}]=\left[\begin{array}{c}0 ; x \leq 10 \text { atau } x \leq 26 \\ \frac{x-10}{7-10} ; 10 \leq x \leq 17 \\ \frac{26-x}{9} ; 17 \leq x \leq 26\end{array}\right]$

$\mu$ HargaMahal $[\mathrm{x}]=\left[\begin{array}{c}0 ; x \leq 17 \\ \frac{26-x}{9} ; 17 \leq x \leq 26 \\ 1 ; x \geq 26\end{array}\right]$ 
2. Spesifikasi Rancangan Program

a) Spesifikasi Bentuk Masukan

Adapun data yang dimasukkan pengguna pada aplikasi sistem pendukung keputusan ini adalah sebagai berikut :

Nama Dokumen : Pertanyaan

Sumber : Pengguna Aplikasi

Media : Android

Jumlah $\quad: 1$

Bentuk : Lampiran A-1

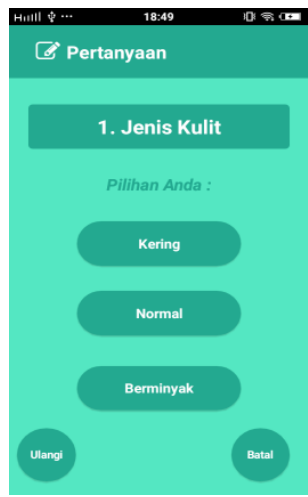

Gambar 1.Tampilan menu pertanyaan

Menu pemilihan facial foam merupakan sebuah form yang berisi pertanyaan dari beberapa variabel dimana pada menu ini pengguna atau user menjawab pertanyaan yang sudah di sajikan pada aplikasi sistem pendukung keputusan, dan menjawab setiap pertanyaan sesuai dengan apa yang dibutuhkan oleh pengguna.

b) Spesifikasi Bentuk Keluaran

Bentuk keluaran merupakan hasil perhitungan dari apa yang dimasukan pengguna dalam menu pertanyaan.Adapun data yang dimasukkan pengguna pada aplikasi sistem pendukung keputusan ini adalah sebagai berikut :

Nama Dokumen : Hasil

Sumber : Program

Media : : Android

Jumlah $\quad: 1$

Bentuk : Lampiran B-1

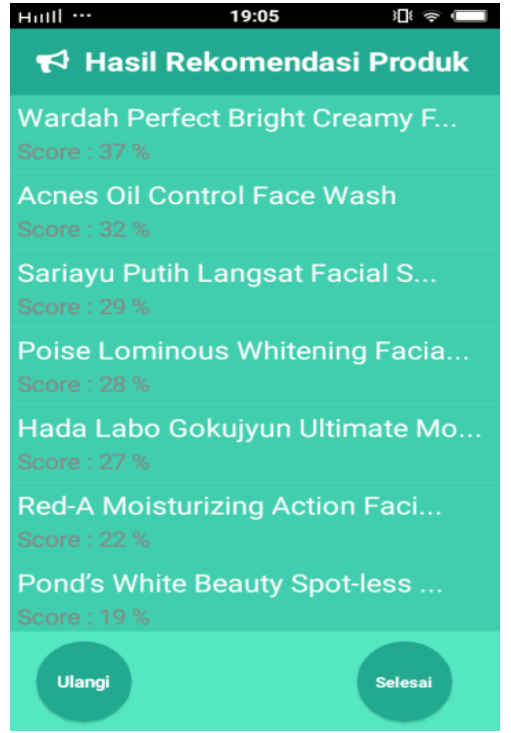

Gambar 2. Bentuk keluaran dari jawaban yang dipilih pengguna

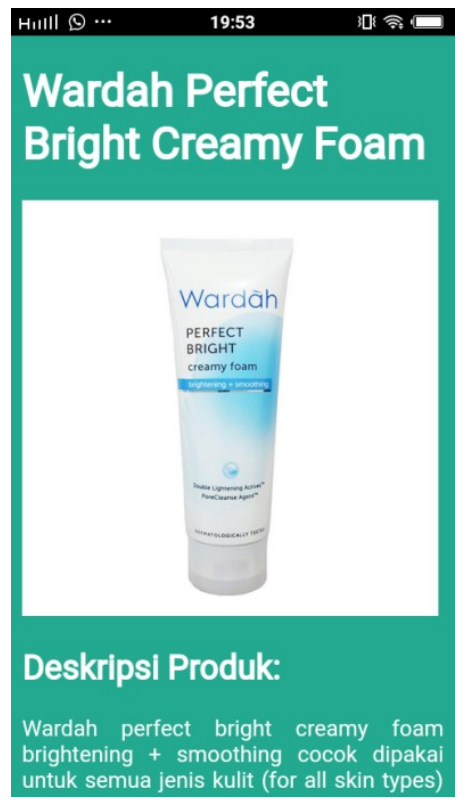

Gambar 3. Bentuk keluaran dari deskripsi produk yang dipilih pengguna

Menu hasil merupakan sebuah form yang menampilkan hasil presentasi produk dari jawaban yang sudah diisi oleh pengguna pada menu pertanyaan. 


\section{Spesifikasi File}

\begin{tabular}{|c|c|c|c|}
\hline No. & $\begin{array}{c}\text { Elemen } \\
\text { Data }\end{array}$ & Tipe & Keterangan \\
\hline 1. & idsistem & Integer & $\begin{array}{c}\text { Primary Key, } \\
\text { Autoincrement }\end{array}$ \\
\hline 2. & dihitung & Integer & \\
\hline
\end{tabular}

Pada aplikasi sistem pendukung keputusan ini terdapat beberapa file. Penjelasan rinci mengenai file-file tersebut adalah sebagai berikut:

a) Spesifikasi File Kriteria

Nama file: data.db

Nama tabel : kriteria

Fungsi :menyimpan semua

\begin{tabular}{|c|c|c|c|}
\hline No. & $\begin{array}{c}\text { Elemen } \\
\text { Data }\end{array}$ & Tipe & Keterangan \\
\hline 1. & idkrt & Integer & $\begin{array}{c}\text { Primary } \\
\text { Key,Autoin } \\
\text { crement }\end{array}$ \\
\hline 2. & idproduk & Integer & \\
\hline 3. & idvar & Integer & \\
\hline 4. & nilai & Real & $\begin{array}{c}\text { Default } \\
0.00\end{array}$ \\
\hline
\end{tabular}

Tipe file

data nilai kriteria

Kunci field

: file master

: idproduk

Software : SQLite

Tabel 1. Spesifikasi file tabel kriteria

b) Spesifikasi File Produk

Nama file: data.db

Nama tabel : produk

Fungsi : : menyimpan daftar

\begin{tabular}{|c|c|c|c|}
\hline No. & $\begin{array}{c}\text { Elemen } \\
\text { Data }\end{array}$ & Tipe & Keterangan \\
\hline 1. & idproduk & Integer & $\begin{array}{c}\text { Primary } \\
\text { Key,Autoin } \\
\text { crement, }\end{array}$ \\
\hline 2. & namaprd & Text & \multicolumn{1}{|c|}{$\begin{array}{c}\text { Default } \\
0.00\end{array}$} \\
\hline 3. & score & Real & $\begin{array}{l}\text { nama produk } \\
\text { : file master } \\
\text { : idproduk } \\
\text { : SQLite }\end{array}$ \\
\multicolumn{3}{|c}{$\begin{array}{l}\text { Tipe file } \\
\text { Kunci Field } \\
\text { Software }\end{array}$} &
\end{tabular}

Tabel 2. Spesifikasi file tabel produk

c) Spesifikasi File Sistem

Nama file: data.db

Nama tabel : sistem

Fungsi : menyimpan data hasil perhitungan

jawaban

Tipe file : file master

Kunci Field : idsistem

Software : SQLite

\begin{tabular}{|c|c|c|c|}
\hline No. & $\begin{array}{c}\text { Elemen } \\
\text { Data }\end{array}$ & Tipe & Keterangan \\
\hline 1. & idvar & Integer & $\begin{array}{c}\text { Primary } \\
\text { Key,Autoincre } \\
\text { ment }\end{array}$ \\
\hline 2. & namavar & Text & \\
\hline 3. & kecil & Real & Default 0.00 \\
\hline 4. & sedang & Real & Default 0.00 \\
\hline 5. & besar & Real & Default 0.00 \\
\hline 6. & txpil1 & Text & \\
\hline 7. & txpil2 & Text & \\
\hline 8. & txpil3 & Text & \\
\hline
\end{tabular}

Tabel 3. Spesifikasi file tabel sistem

d) Spesifikasi File Variabel

Nama file: data.db

Nama tabel : variabel

Fungsi : menyimpan data variabel yang digu nakan sebagai pertanyaan.

Tipe file : file master

Kunci Field : idvar

Software :SQLite

Tabel 4. Spesifikasi file tabel variabel

\section{HIPO}

HIPO (Heirarchy Plus Input Process Output) dari sistem pendukung keputusan pemilihan skincare adalah sebagai berikut :

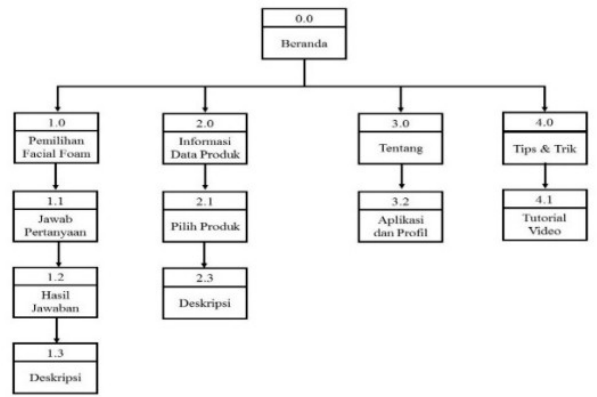

Gambar III.26. Diagram HIPO

\section{Spesifikasi Program}

Spesifikasi program dalam pembuatan aplikasi sistem pendukung keputusan ini adalah sebagai berikut : 
a) Menu Utama

Nama Program : Main
Akronim $\quad:$ lymain
Fungsi $\quad$ tampilan utamayang
dapat mengakses semuamenu
Bahasa pemograman : basic
Proses : ketika membukaaplikasi
otomatisakan masuk kemenu utama

b) Menu Informasi Data Produk

$\begin{array}{ll}\text { Nama Program } & \text { : Produk } \\ \text { Akronim } & \text { : lyproduk } \\ \text { Fungsi } & \text { :untuk melihatdaftar }\end{array}$
data produk beserta deskripsi dari masing-masing produk

Bahasa pemograman : basic

Proses : tekan tombol informasi data produk dan pilih produk yang ingin dilihat, maka akan muncul deskripsi dari produk tersebut.

c) Menu Tentang

$\begin{array}{ll}\text { Nama Program } & \text { : Tentang } \\ \text { Akronim } & : \text { Iytentang } \\ \text { Fungsi } & : \text { untuk melihat }\end{array}$ deskripsi mengenai aplikasi dan profil pembuat aplikasi

Bahasa pemograman : basic
Proses : tekan tombol tentang, maka akan muncul deskripsi mengenai aplikasi dan profil singkat pembuat aplikasi.

d) Menu Tips \& Trik
Nama Program
: Tips
Akronim
: lytips
Fungsi
: untuk melihat tips
\& trik mengenai perawatan wajah
Bahasa pemograman
basic
Proses
tekan tombol tips
$\&$ trik, dan pilih video tutorial yang ingin diliat.

\section{Flowchart}

Flowchart merupakan sebuah bagan yang memiliki arus untuk menggambarkan suatu langkah penyelesaian dalam suatu masalah.Flowchart merupakan cara penyajian dari suatu algoritma. Berikut merupakan flowchart dari aplikasi ini.

\section{a) Flowchart Menu Utama}

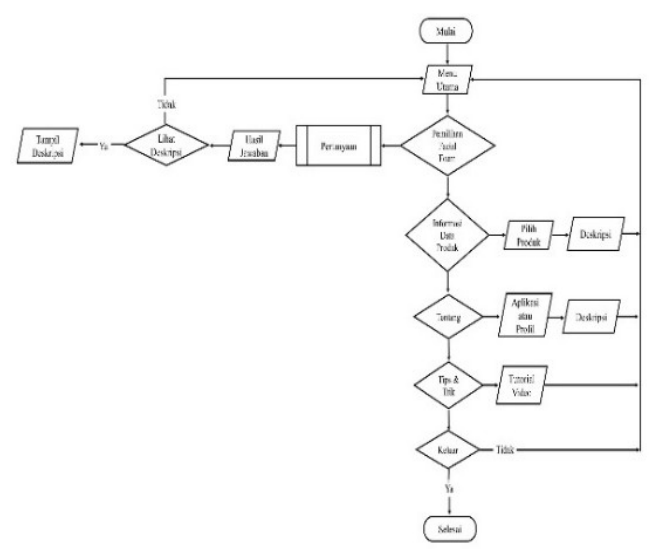

Gambar III.27. Tampilan Flowchart Menu Utama

Ketika kita membuka aplikasi sistem pendukung keputusan ini pada menu awal akan ada 4 button yaitu Pemilihan Facial Foam, Informasi Data Produk, Tentang, dan Tips \& Trik.

\section{b) Flowchart Menu Pemilihan Facial Foam}

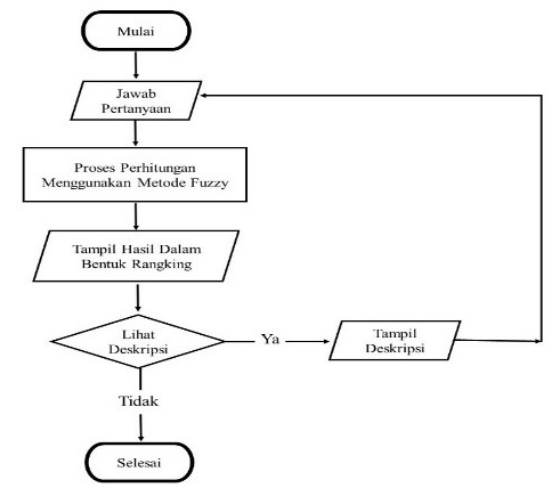

Gambar III.28. Tampilan Flowchart Menu Pemilihan Facial Foam

Pada menu utama jika user memilih menu pemilihan facial foam maka sistem akan membuka sebuah halaman yang berisi seluruh pertanyaan dari beberapa variabel yang disediakan dan user akan menjawab pertanyaan sesuai dengan keinginan. Setelah pertanyaan tentang pemilihan facial foam itu selesai, maka sistem akan otomatis menyimpan atau merekap data tersebut dan hasil perhitungan serta produk yang cocok untuk dipakai akan muncul. 
Setelah itu userpun dapat melihat deskripsi produk yang dipilih atau dapat dilihat pada menu informasi data produk.Dan didalamnya terdapat tombol ulangi dan selesai.

\section{E. KESIMPULAN DAN SARAN}

\section{Kesimpulan}

Berdasarkan pembahasan dan hasil yang diperoleh, maka dapat disimpulkan :

a) Aplikasi sistem pendukung keputusan pemilihan skincare berbasis android yang dibuat untuk mempermudah pengguna dalam memperoleh informasi serta memberi pengetahuan tentang berbagai jenis produk facial foam yang baik untuk digunakan berdasarkan jenis kulit yang dimiliki oleh pengguna. User dapat memilih jawaban sesuai dengan kebutuhan dan keinginan pada menu pemilihan facial foam sehingga user dapat memahami tentang produk yang dipilih.

b) Dengan adanya aplikasi sistem pendukung keputusan ini dapat menjadi alternatif dalam pemilihan produk kecantikan.

c) Sistem pendukung keputusan ini mengunakan metode Logika Fuzzy, karena dapat memberikan hasil yang akurat yang didapatkan dari perhitungan berdasarkan jawaban yang dipilih pengguna.

d) Aplikasi ini tidak memberikan solusi penyembuhan penyakit kulit.

\section{DAFTAR PUSTAKA}

[1] Astika, D. M., Dwi, K., \& Windi, I. (2017). Aplikasi Pelayanan Jasa Persediaan bahan Baku Pada Laundry Q Pontianak. Jurnal Khatulistiwa Informatika, V(2), 112-117.

[2] Firmansyah, R. (2017). Fuzzy Decision Support System ( Fdss ) Untuk Seleksi Penerimaan Siswa Baru. Indonesian Journal on Computer and Information Technology, 2(1), 17-25.

[3] Maarif, V., Nur, H. M., \& Rahayu, W. (2018). Aplikasi pembelajaran ilmu tajwid berbasis android. Evolusi, 6(1), 91-100. Retrieved from https://ejournal.bsi.ac.id/ejurnal/index.php /evolusi/article/view/3586

[4] Maarif, V., Widodo, A. E., \& Wibowo, D. Y. (2017). Aplikasi Tes IQ Berbasis Android. ljse.Bsi.Ac.Id IJSE - Indonesian Journal on Software Engineering ISSN, 3(2),
2461-2690.

[5] Maryani, Sayed Fachrurrazi. (2017). Sistem Pendukung Keputusan Pemilihan Kosmetik Produk Latulipe yang Sesuai Dnegan Jenis Kulit Wajah Perempuan Indonesia Menggunakan Metode Promethee. Jurnal Sistem Informasi ISSN : 2598-599X

[6] Riza, R., Hasbi, M., \& Prabowo, I. A. (2018). Sistem Pendukung Keputusan Penanganan Pasien Ugd Menggunakan Metode Fuzzy Multiple Attribute Decision Making Dengan Simple Additive Weighting Pada Puskesmas Gajahan Surakarta. Jurnal Teknologi Informasi Dan Komunikasi (TIKomSiN), 6(1), 2128.

https://doi.org/10.30646/tikomsin.v6i1.34 8

[7] Sari, N. M. (n.d.). Dengan Jenis Kulit Wajah Menggunakan Pendekatan Fuzzy Logic. 543-550.

[8] Sari, R. (2018). Jurnal Evolusi Volume 6 No 2 - 2018. Evolusi, 6(2), 57-65. 